\title{
振動状態に末ける粉体の流動性*
}

\author{
荒川正文** 西 野 操 ${ }^{* * *}$ 水 渡 英 二**
}

\section{The Flow Property of Powder in Vibrating State}

by

\section{Masafumi Arakawa, Misao Nishino and Eiji Suito}

(Institute for Chemical Research, Kyoto University, Uji)

\begin{abstract}
The viscosity of powder was measured with the rotational viscometer in a vibrating state. In this experiment, the outer cylinder of Stomer viscometer was tightly connected to the vibrator which had constant frequency (120cps), and the amplitude was varied by changing the voltage applied to the vibrator. The $\alpha$-alumina powders with several kinds of particle sizes were used as samples.

The flow curves, obtained of powders of various particle sizes under different amplitudes and temperatures, were found to be similar to one of non-Newtonian liquids. When the amplitude decreased, each powder behaved like a continuous solid.

The apparent viscosity was obtained from these flow curves in relation to the different amplitudes and particle sizes. At a constant rate of shear and large amplitude, the apparent viscosity decreased with decrease in particle size. When the amplitude was sufficiently small, the apparent viscosity reached its minimum at a definite particle size. It was considered that in the fine powders their coagulated secondary particles moved as flowing units, and that these coagulated particles were broken into primary particles with increase of amplitude.

(Received Feb. 12, 1968)
\end{abstract}

\section{1 緒言}

粉体の力学的諸現象が構成粒子の付着・凝集性によ って著しく影響されることはよく知られた事実である。 著者らはさきに, 粉体の充てん性が粒子間凝集力と粒 子の重さ（慣性力）とのつりあいとして説明できるこ とを報告した。すなわち，粒子径の減少に伴う粒子の 重さの減少度は粒子間凝集力(たと光ば van der waals 力）の減少度より大きいので, 微粉体になるほど見掛 けの凝集力が増大し，かさ高い充てん構造をとるよう になる。この場合, 粒子の重さは静荷重ではなく慣性 力であるから，粒子の慣性力を充分大きくしてやれば， 粒子間凝集力の影響が無視できるようになり, 微粉体 も粗粉体と同様な挙動をとると思われる。そこで本研 究では, その一つとして振動状態においた粉体の性質 を取り扱ってみた。粉体層に振動を与えると流動しや すくなることは日常よく経験するところである。たと えば, 粉体を容器に入れて振動を与えると, 粉体層が “柔らかく”なり棒で自由にかき回わすことのできる ような状態になる。液体の粘性,すなわら, 内部摩擦 が液体の分子間力によるものであることを考光ると， 上の上らに粉体を振動状態に沶いて，“柔らかく”な

* 原稿受理 昭和 43 年 2 月 12 日

** 正会員 京都大学化学研究所 宇台市五ケ庄

*** 京都大学化学研究所 宇治市五ケ庄
ったところで液体の粘度測定と同じ手段を用いて粉体 の “粘度”を測定すれば，粉体の粒子間相互作用や粒 子間凝集力関するなんらかの知見が得られるのでは ないかと考兄られる。この観点に立って以下の実験を 行なった．粉体の振動状態そのものが非常に複雑で, まだ定量的な結果を得るに至っていないが，粉体物性 の一つの研究手段としての可能性をもつものと考兄る ので報告する.

\section{2 実験}

試料粉体は研摩剤として市販されている $\alpha$ ーアルミ ナ（商品名ホワイトアランダム，富士見研摩剂工業 (株)）で，粒子の大きさは Table I 飞示すと预りで ある.

装置は Fig. 1 に示すとおりで，本体は市販のスト Table I. Sample and its particle size.

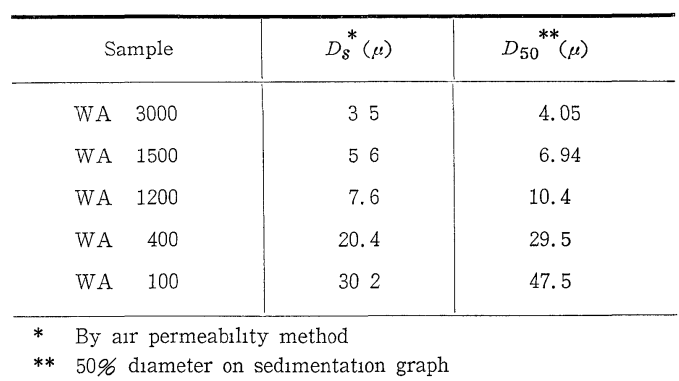




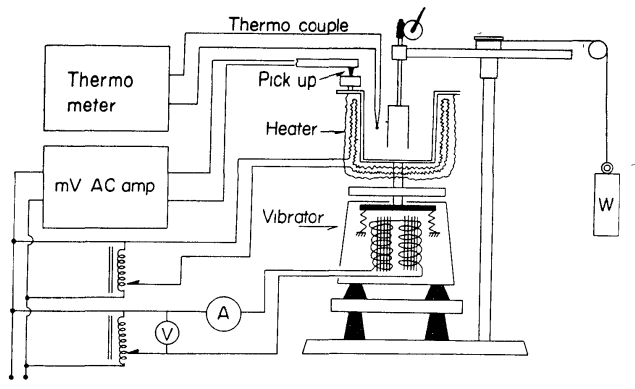

Fig. 1. Schematic diagram of the apparatus.

ーマー粘度計である。ただし，外筒は内径 $6 \mathrm{~cm}$, 深さ $6 \mathrm{~cm}$, 内筒は外径 $2 \mathrm{~cm}$, 長さ $4 \mathrm{~cm}$, , 外筒の内面お よび内筒の外面にはすべりを防止するために約 $1 \mathrm{~mm}$ 間隔で縦みぞを刻んである。外筒はバイブレータに固 定し，かつ試料を加熱できるように外筒の回りにバン ドヒータを巻いた。 バイブレータは振動数が $120 \mathrm{cps}$ に固定されているので，スライダックを用いてバイブ レータに加える電圧を変えることにより振動の強度を 変化させた，すなわち，振動状態としては振幅だけが 変わるのである。その振幅の測定は外筒の上端にピッ クアップを接し, 電気的振動に変換した後, 交流増幅 し，出力の大きさを電圧計で読み取るよらにした。た だし，本装置では振幅の絶対值は求められず，読み取 られる值は電流值 $\mu \mathrm{A}$ で表示され, 振幅の相対的な大 きさを表わすだけである。な和，加熱温度の影響を避 けるためにピックアップは試料筒に直接接触させず, 間に銅製小型セルを置いてこれに水を循環させた。

実験は，空気中の湿度の影響を避けるために，試料 粉体を $100^{\circ} \mathrm{C}$ に加熱した状態で行なった。

\section{3 結果}

一定量の試料粉体を外筒に入れ, 一定の電圧をか活 て粉体を振動させ，荷重 $W$ をかけると内筒が回転し はじめてほ演定常状態に達する。荷重 $W(\mathrm{~g})$ をいろ
いろ変えてそのときの内筒の回転速度 $R(\mathrm{rev} / \mathrm{sec})$ を 測定し，WとR の関係を求めると，たとえば Fig. 2 のような流動曲線が得られる。これらはいわゆる構造 粘性をもった液体の流動曲線によく似ている，電圧が 高くなるとこの曲線がたってくるが，電圧が低い場合 には荷重が小さい間はこう配が小さく，ある $W$ 值か ら急激にたってくる。このところでは明らかに内筒の 外面と粉体層との間にすべりが起こって沶り, 異常に 早い速度で回転している。このすべりは折点より $W$ の小さいところでも部分的に起こるので回転のしかた が不均一であり, Fig. 2 に知印で示したようにこのよ らな状態では非常にばらつきが大きい，電圧が高い場 合にはばらつきは図に示した程度であるが，Wが大 きくなるとやはりすべりを生じて曲線がたってくる.

Fig. 3 は WA 1500 で, 同様に電圧が低くなると こう配が小さくなり，あるところですべりが起こるが， 電圧が低くなる注どこのすべりの起こる荷重 $W$ が大 きくなる，この状態の極限は，応力の小さい間はまっ たく流動せず, ある応力澾するとすべりのみが起こ るといら固体的挙動になると思われる。この㑯向はど の粒子についても同様であったが，最も粒子径の小 さいWA 3000 だけは多少様子が異なる. Fig. 4 は WA 3000 の流動曲線であるが，この場合には電圧を 低くしても初めのこう配は小さくなるが，かなり小さ な応力ですべりが起こる。

また試料粉体の加熱温度を変えると流動状態に変化 がみられた。 Fig. 5 は WA 3000 について加熱温度 を変えたときの流動曲線の変化を示したもので, 明ら かに温度が高くなると粘度が上昇する。しかし，この 加熱温度による流動曲線の変化は, 粒子径が大きくな るに従って小さくなり, Fig. 6 のように WA 400 で はほとんど差異が認められなくなる。

\section{4 考察}

非ニュートン流体ではせん断応力とせん断速度の比

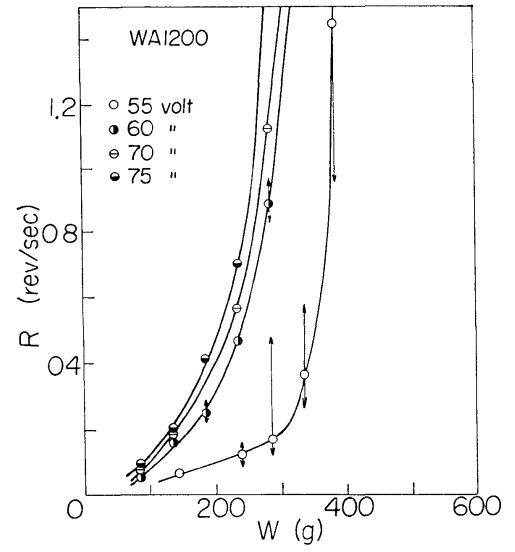

Fig. 2. Flow curves for WA 1200

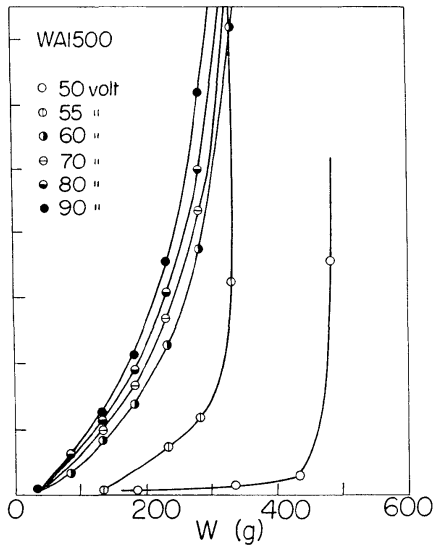

Fig. 3 Flow curves for WA 1500.

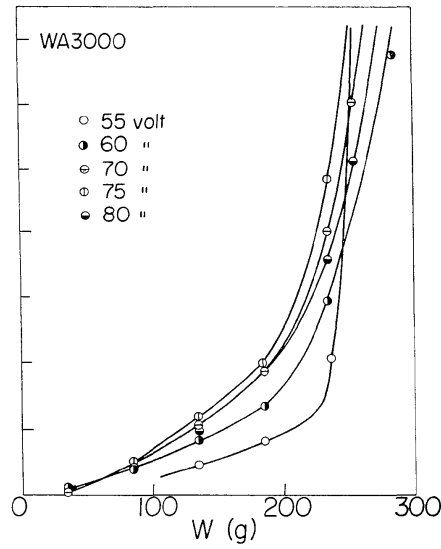

Fig. 4. Flow curves for WA 3000 


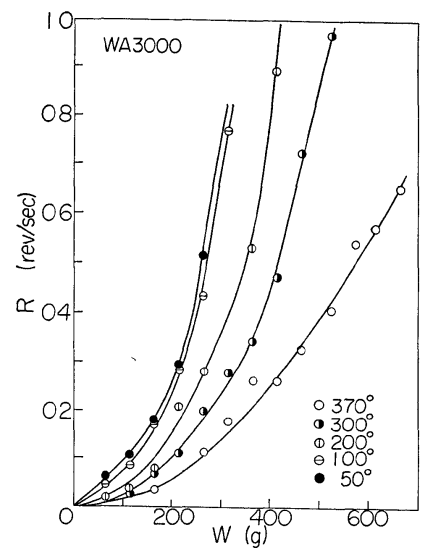

Fig. 5. The effect of temperature upon the flow properties of the powder composed of small particles.

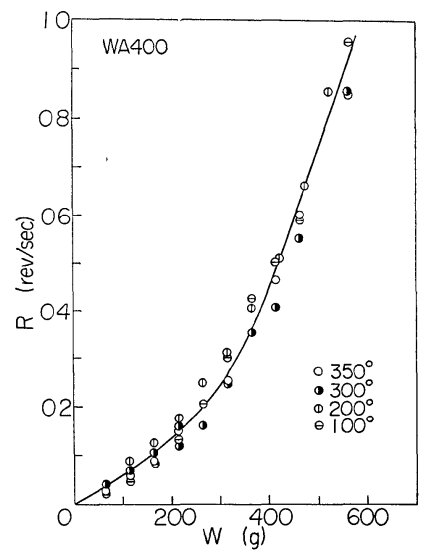

F1g. 6. The effect of temperature upon the flow properties of the powder composed of large particles.

を見掛けの粘度として取り扱らが，本研究でもこれに 習って Fig. 2 などの流動曲線から見掛けの粘度 $\eta_{a}$ を 求め, 振動状態や粒度に上る変化を求めた.

ストーマー型粘度計では試料の粘度 $\eta$ は(1)式で与兄 られる。

$$
\begin{aligned}
& \eta=\frac{T}{\Omega} \cdot \frac{1}{4 \pi h}\left(\frac{1}{r_{1}^{2}}-\frac{1}{r_{2}^{2}}\right) \\
& T=W d
\end{aligned}
$$

ただし $r_{1}, r_{2}$ はそれぞれ内筒および外筒の半径， $h$ は内筒の試料層に浸っている深さ， $\Omega$ は内筒の回転角 速度，Tは内筒にかかるトルク， $d$ は内筒の上に取り 付けた滑車の半径である. 本実験では内筒と外筒の間 隙が大きいこと, 筒面とみぞをつけてあることなどが 誤差になると思われるので, これらを装置定数 $k$ の中 に含め

$$
\eta_{a}=k \cdot \frac{1}{h} \cdot \frac{W}{R}
$$

として(2)式を用いた。 $k$ はヒマシ油を用いて求めた。

まず，見掛けの粘度の荷重 $W$ による变化を求めた。

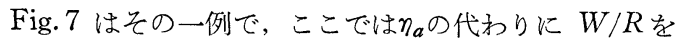

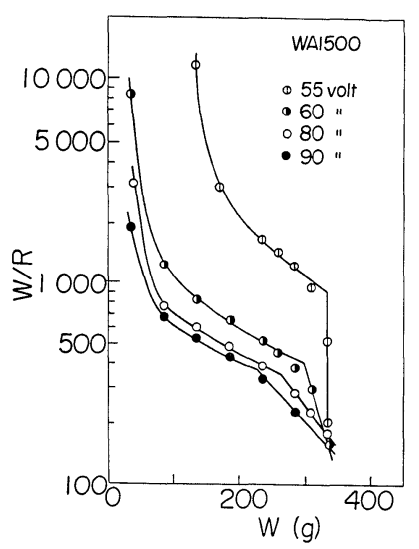

Fig. 7. Relation between apparent viscosity and shearing stress.

対数目盛でとってある. 応力が小さい間は見掛け粘度 が非常に大きく，応力が大きくなるにつれてだんだん 小さくなる.構造粘性の場合にはこれが一定値に近づ くわけであるが，この場合にはあるところで急激に小 さくなり曲線に折れめができる。これはすべりが起こ る点に相当すると考兄られる。電圧が低い場合にはこ の折れ曲りが非常にシャープである。電圧が高くなっ てもこの折れ曲りは存在し, 流動曲線でははっきりし なかったすべりの起こる点もこのように描くと明確に とらえることができる。この折机曲り点は, 特和ざっ ぱに言って電圧が高くなる汪ど見掛け粘度の低くから $W$ の小さいところに現われる。 そこで一応この折れ 曲り点が一つの系に固有のものと考皇て, 各試料につ いてこの点に和ける見掛け粘度 $\eta_{a, c}$ および荷重 $W_{c}$ の電压による変化を比較してみた。

Fig. 8 は $W_{c}$ の電圧による変化を示したもので, ある電圧で急に $W_{c}$ が減少してあとゆるやかに変化 する，この場合， $W_{c}$ の減少する電圧は粒子径が大き

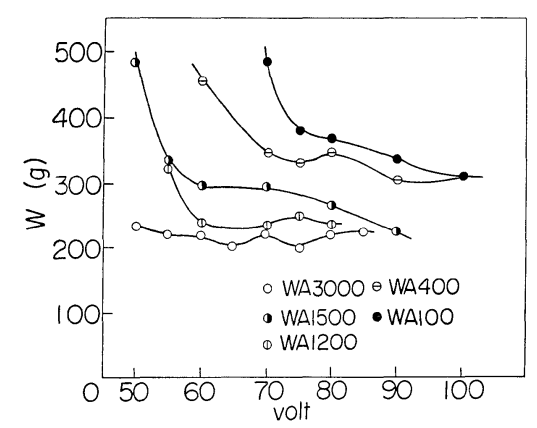

Fig. 8. Relation between critical shearing stress and voltage given to vibrator. 
い洰ど大きいが，WA 3000 だけは $W_{c}$ の低下が明 確でなくほぼ一定値である。一方， $\eta_{a}, c$ と電圧の関 係は Fig.9 のようになる。いずれも電圧が大きくな

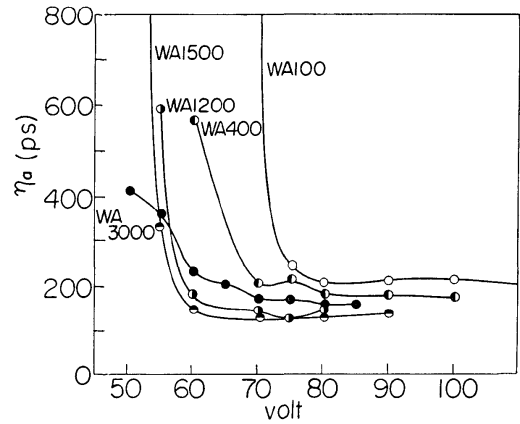

Fig. 9. Relation between critical apparent viscosity and voltage given to vibrator.

ると急激に $\eta_{a, c}$ が減少し，多少の上下はあるがほぼ 一定となる。 $\eta_{a}, c$ の急激な减少は粒子径が小さくな る汇ど低電圧で起こるが，WA 3000 だけは様子が異 なっており， $\eta_{a, c}$ の減少のしかたが他の試料に比べる とゆるやかで, から WA 1500 やWA 1200 など粒 子の大きい試料より高い電圧で起こっている.

このように流動性が急変する電圧が粒子の大きさに よって変わるが，これは同じ電圧をかけても粉体粒子 の振動状態が異なるためだと考えられる．Fig. 10 は

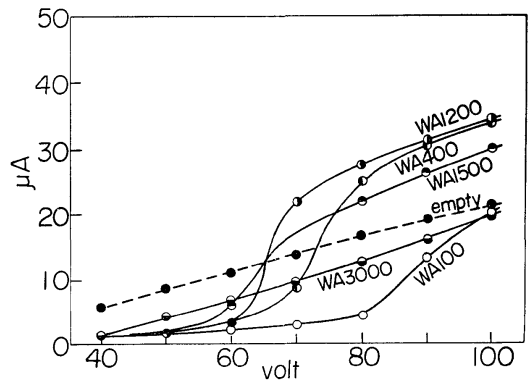

Fig. 10. Relation between amplitude of cylinder filled with powder and voltage given to vibrator.

電圧と振幅の関係を示したものである。ただしこの場 合，上下振動の振幅をピックアップで検出しているこ とと, 電気的変換が直線的でない可能性もあることか ら, 振動計の電流值が振幅の絶対值に比例しない危険 性はあるが，一定の条件の下では，たとえば，空の容 器の振動については破線で示したように一定の関係が 得られるので, 便宜的にこの電流值を振幅として相対 的な比較を行なうことにした。粉体を入れて電圧を上 げていくと，電圧の低い間は空のときに比べて振幅が 小さいが，ある電圧から急激に振幅が上昇する。この 変化は粒子径が大きいもの汪ど高い電圧で起こり，こ
れは $\eta_{a}, c$ や $W_{c}$ が急激に小さくなる電圧と一致して いる. WA 400〜1500 の試料では振幅が空の場合よ り大きくなるが，これは共振が起こっているためと思 われる。この図に执いても，WA 3000 だけが他の試 料と異なった挙動をとり，転位点はなく，なだらかな 変化をしている。これは $\eta_{a}, c$ や $W_{c}$ の変化の状態と 対応している。

このように電圧によって粉体の振動状態が変化する ので，粒子に加わる外力が同じとき，すなわち振幅が 同じで，から速度こら配が同じ，すなわら，Rが一定 のときの各試料の見掛仔粘度を比較してみた。この場 合， $R$ としてはすべりの起こらない範囲のものをとっ て， $R=0.2$ とすると，このときの見掛け粘度 $\eta_{a}$ の振 幅による変化は Fig. 11 のようになる。このように表

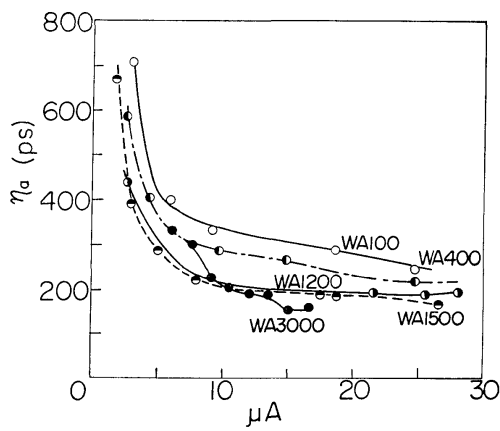

F1g. 11. Variation of apparent viscosity with amplitude at constant rate of shear.

わすと, WA 3000 以外の粉体はいずれも添同様の 傾向を示し，見掛け粘度は粒子が小さくなるに従って 低くなっている. WA 3000 の $\eta_{a}$ は振幅が小さいと きは WA 400 と同じ程度であるが，振幅が大きくな るにつれて小さくなっている.

振動状態にある粉体粒子の運動を分子の熱運動に対 応させてみると, 与えられた振動の強度は分子運動に 対する温度の役割に相当すると考兄られる。極端に言 えば，静止状態の粉体は絶対零度の物質の状態に対応 するわけである，振動を強くしていくと，粒子が運動 しはじめて固体的挙動から液体的な挙動をとるように なる，振動が強くなると粘度が下がるのは，液体の粘 度の温度依存性に対応する。気体では分子運動が激し いので，分子の衝突によって速度の平均化が行なわれ， 気体の粘度は温度が上がるにつれて増大する，粉体の 振動の場合にも，振度強度が大きくなると粒子間の衝 突が激しくなり，気体的な粘性挙動をとることが期待 される。乙かし，本実験の場合は上下振動だけを与え ているので粒子は均一な三次元的運動をしていない. したがって，分子運動に直接対応させることはできな いが，Fig. 9 に部分的に見られるよらな $\eta_{a}$ 電圧関係 が上昇する傾向は，上に述べたような粒子の運動状態 
の変化によるものと考光られる. Fig. 9 の $\eta_{a}$ の変化 の平坦な部分は, 液体的に粘度が下がる傾向と気体的 に上がる傾向との重なりであるとみることもできる。

粘度に対する粒度の影響をみるために，Fig. 11 に おいて，振幅が一定のときの見掛け粘度と粒子径の関 係を求めると，Fig.12 亿示すよらになった。粒子径

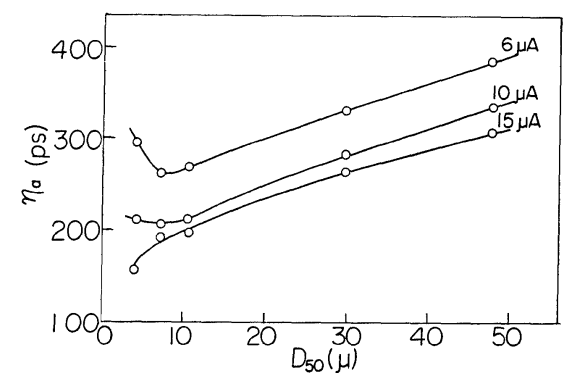

Fig. 12. Relation between apparent viscosity and partıcle size.

が大きくなると見掛け粘度も上昇するが，振幅が小さ い場合には $6 \sim 7 \mu$ 付近に極小ができる，振幅が大き
くなると極小がなくなり, 粒子径の減少とともに見掛 け粘度も低下する。このことは，たと兊ばタッピング

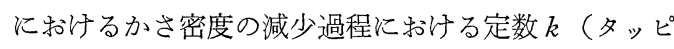
ングのされやすさを表わす定数）の粒度依存性によく 似ている。 タッピングの場合には極小点より粒子径の 小さい粉体では, 粒子が凝集していて凝集二次粒子が 運動単位となっていると考兄られた。この場合にも, 振動強度が弱いとさには凝集粒子が流動単位として運 動するために見掛け粘度が大きく, 振動が強くなると 凝集粒子がこわれて流動単位が小さくなるのではない かと考光られる。

な拈，Fig. 5 および 6 に示した加熱温度の影響はな にに起因しているのかわからないが，今後検討を進め る予定である。

(昭和42年10月19日 第 5 回粉体汇関する討論会化て緸容)

\section{参考文 献}

1）荒川正文，水渡英二，材料， 17， No. 178 （1968）掲載 予定.

2）荒川正文，岡田隆三，水渡英二，材料， 14，764 (1965). 